\title{
Futile Cycling of Lactate Through the Plasma Membrane of C6 Glioma Cells as Detected by $\left({ }^{13} \mathrm{C},{ }^{2} \mathrm{H}\right) \mathrm{NMR}$
}

\author{
Tiago B. Rodrigues, ${ }^{1,2}$ Heather L. Gray, ${ }^{1}$ Marina Benito, ${ }^{1}$ Susana Garrido, ${ }^{1}$ \\ Alejandra Sierra, ${ }_{1}^{1}$ Carlos F. Geraldes, ${ }^{2}$ Paloma Ballesteros, ${ }^{3}$ and Sebastián Cerdán ${ }^{1 \star}$ \\ ${ }^{1}$ Instituto de Investigaciones Biomédicas "Alberto Sols" CSIC/UAM, Madrid, Spain \\ ${ }^{2}$ Departamento de Bioquímica e Centro de Neurociências e Biologia Celular, Faculdade de Ciências e \\ Tecnologia, Universidade de Coimbra, Coimbra, Portugal \\ ${ }^{3}$ Laboratorio de Síntesis Orgánica e Imagen Molecular, UNED, Madrid, Spain
}

We report a novel $\left({ }^{13} \mathrm{C},{ }^{2} \mathrm{H}\right)$ nuclear magnetic resonance (NMR) procedure to investigate lactate recycling through the monocarboxylate transporter of the plasma membrane of cells in culture. C6 glioma cells were incubated with $\left[3-{ }^{13} \mathrm{C}\right]$ lactate in Krebs-Henseleit Buffer containing $50 \%{ }^{2} \mathrm{H}_{2} \mathrm{O}$ (vol/vol) for up to $30 \mathrm{hr} .{ }^{13} \mathrm{C}$ NMR analysis of aliquots progressively taken from the medium, showed: (1) a linearly decreasing singlet at $\sim 20.85$ parts per million (ppm; $-0.119 \mu \mathrm{mol} / \mathrm{mg}$ protein/hr) derived from the methyl carbon of $\left[3-{ }^{13} \mathrm{C}\right]$ lactate; and (2) an exponentially increasing shifted singlet at $\sim 20.74 \mathrm{ppm}(0.227 \mu \mathrm{mol} /$ $\mathrm{mg}$ protein/hr) from the methyl carbon of $\left[3-{ }^{13} \mathrm{C}\right.$, $2-^{2} \mathrm{H}$ lactate. The shifted singlet appears because during its transit through the cytosol, $\left[3-{ }^{13} \mathrm{C}\right]$ lactate generates $\left[3-{ }^{13} \mathrm{C}, 2-{ }^{2} \mathrm{H}\right]$ lactate in the lactate dehydrogenase (LDH) equilibrium, which may return to the incubation medium through the reversible monocarboxylate carrier. The methyl group of $\left[3-^{13} \mathrm{C}, 2-{ }^{2} \mathrm{H}\right]$ lactate is shifted $-0.11 \mathrm{ppm}$ with respect to that of $\left[3-{ }^{13} \mathrm{C}\right]$ lactate, making it possible to distinguish between both molecules by ${ }^{13} \mathrm{C}$ NMR. During incubations with $2.5 \mathrm{mM}\left[1-{ }^{13} \mathrm{C}\right]$ glucose and $3.98 \mathrm{mM}\left[\mathrm{U}-{ }^{13} \mathrm{C}_{3}\right]$ lactate or with $2.5 \mathrm{mM}\left[1-{ }^{13} \mathrm{C}\right]$ glucose and $3.93 \mathrm{mM}\left[2-{ }^{13} \mathrm{C}\right]$ pyruvate, $\mathrm{C} 2$-deuterated lactate was produced only from $\left[1-{ }^{-13} \mathrm{C}\right]$ glucose or $\left[\mathrm{U}-{ }^{13} \mathrm{C}_{3}\right]-$ lactate, revealing that this deuteration process is redox sensitive. When $\left[1-{ }^{13} \mathrm{C}\right]$ glucose and $\left[\mathrm{U}^{13} \mathrm{C}_{3}\right]$ lactate were used as substrates, no significant $\left[3-{ }^{13} \mathrm{C}\right]$ lactate production from $\left[1-{ }^{13} \mathrm{C}\right]$ glucose was detected, suggesting that glycolytic lactate production may be stopped under the high lactate concentrations prevailing under mild hypoxic or ischemic episodes or during cerebral activation.

๑) 2004 Wiley-Liss, Inc.

Key words: lactate recycling; monocarboxylate transporter; MCT1; C6 cells; ${ }^{13} \mathrm{C}$ NMR

Lactate is thought to play a central role in cerebral pathophysiology both as an energy substrate for the brain and as a metabolic coupling intermediate between neurons and glial cells (Bouzier et al., 1998a,b; Qu et al., 2000;
Bouzier-Sore et al., 2001, 2003; Dienel and Hertz, 2001; Cater et al., 2003; Pellerin, 2003; Smith et al., 2003). In particular, lactate is believed to provide the coupling mechanism between the increased consumption of glucose observed during cerebral activation and the energy demanded by neurons during glutamatergic neurotransmission (Magistretti and Pellerin, 1997, 1999; Dienel and Hertz, 2001; Pellerin et al., 2002; Dienel and Cruz, 2003; Garcia-Espinosa et al., 2003, 2004). Moreover, lactate is thought to serve as a vital substrate for neuronal recovery after hypoxia or ischemia (Muller et al., 1994; Schurr et al., 2001; Schurr, 2002; Cater et al., 2003), to contribute primarily to cerebral energetics (Pellerin and Magistretti, 2004) and to modulate intra- and extracellular pH (GarcíaMartín et al., 2001b).

Abbreviations: BCA, bicinchoninic acid; CPD, composite pulse decoupling; DMEM, Dulbecco's modified Eagle medium; FBS, fetal bovine serum; GAPDH, glyceraldehyde 3-phosphate dehydrogenase (EC 1.2.1.12); Glc, glucose; HEPES, $N$-[2-hydroxyethyl]piperazine- $N^{\prime}$-[2-ethanesulfonic acid]; Lac, lactate; $\mathrm{LDH}$, lactate dehydrogenase (lactate $\mathrm{NAD}^{+}$oxidoreductase, EC 1.1.1.27); MCT1, monocarboxylate transporter 1; NMR, nuclear magnetic resonance; Pg, cytosolic pyruvate pool originating from glucose; Pp, cytosolic pyruvate pool originating from extracellular pyruvate or lactate; Pyr, pyruvate; TCA, tricarboxylic acid.

Contract grant sponsor: Spanish Ministry of Education and Science; Contract grant number: SAF 2001-2245; Contract grant sponsor: Institute of Health Carlos III; Contract grant number: FISss C03/08, G03/155, C03/ 10; Contract grant sponsor: Community of Madrid; Contract grant number: Strategic Group Grant 2000-3; Contract grant sponsor: JUSTESA IMAGEN SA; Contract grant number: Institutional support grant 20032007; Contract grant sponsor: Fundação para a Ciência e Tecnologia; Contract grant number: SFRH/BD/5407/2001.

${ }^{\star}$ Correspondence to: Dr. Sebastián Cerdán, Laboratory for Imaging and Spectroscopy by Magnetic Resonance (LISMAR), Instituto de Investigaciones Biomédicas, "Alberto Sols" CSIC/UAM, c/ Arturo Duperier 4, E-28029 Madrid, Spain. E-mail: scerdan@iib.uam.es

Received 28 June 2004; Revised 23 August 2004; Accepted 26 August 2004

Published online 23 November 2004 in Wiley InterScience (www. interscience.wiley.com). DOI: 10.1002/jnr.20308 
Intracellular lactate production is normally small under physiologic conditions, increasing significantly in hypoxic or ischemic situations (Schurr et al., 2001; Schurr, 2002; Cater et al., 2003). In these circumstances, the respiratory chain is unable to reoxidize the reducing equivalents produced by glycolysis, causing pyruvate to be reduced to lactate rather than oxidized (Perrin et al., 2002). Increased intracellular lactate may then be extruded to the extracellular space through the proton-linked monocarboxylate transporter (MCT) (Jackson and Halestrap, 1996; Halestrap and Price, 1999; Halestrap and Meredith, 2004). Reduced oxygen tension and compromised blood flow under hypoxic or ischemic conditions preclude lactate oxidation and removal, resulting in lactate accumulation in the extracellular space. Under these conditions, extracellular lactate may reach concentrations even higher than those found in the intracellular space, eventually returning back to the cytosol, down its concentration gradient through the reversible MCT. Lactate molecules therefore are able to recycle between extracellular and intracellular compartments, an advantageous situation that makes lactate ubiquitously available. Despite intensive research on lactate metabolism, however, to our knowledge no previous studies have investigated lactate recycling through the plasma membrane. This is due probably to the necessity to distinguish between lactate transport and metabolism and to differentiate those lactate molecules entering the cell from those leaving it, a very difficult aspect for conventional methodologies.

Recently, our laboratory has proposed and implemented hydrogen turnover measurements as alternatives to the classic approaches based on ${ }^{13} \mathrm{C}$ or ${ }^{14} \mathrm{C}$ turnover (Chapa et al., 2000; García-Martín et al., 2001a, 2002). Our method uses ${ }^{13} \mathrm{C}$ nuclear magnetic resonance $\left({ }^{13} \mathrm{C}\right.$ NMR $)$ to follow the exchange of preexisting ${ }^{1} \mathrm{H}$ by ${ }^{2} \mathrm{H}$, when metabolism occurs in media containing a ${ }^{13} \mathrm{C}$-labeled substrate and ${ }^{2} \mathrm{H}_{2} \mathrm{O}$ (Moldes et al., 1994; García-Martín et al., 2002). We herein report on an extension of this approach to monitor lactate recycling in cultures of C6 glioma cells. The method is based on the fact that the $\mathrm{H} 2$ hydrogen of lactate is exchanged rapidly by a deuteron in the lactate dehydrogenase (LDH) equilibrium, only in those lactate molecules that have passed through the cytosol.

\section{MATERIALS AND METHODS}

\section{Cell Culture and Incubation Conditions}

The experimental protocols used in this study were approved by the appropriate institutional review committees and meet the guidelines of their responsible governmental agency. C6 glioma cells were obtained from a local representative of the American Tissue Culture Collection (LGC Promochem, Barcelona, Spain). Briefly, C6 glioma cells were grown to confluence in Dulbecco's modified Eagle medium (DMEM) supplemented with 5\% fetal bovine serum (FBS), $100 \mu \mathrm{g} / \mathrm{mL}$ streptomycin, $25 \mu \mathrm{g} / \mathrm{mL}$ gentamycin, $100 \mathrm{U} / \mathrm{mL}$ of penicillin and Fungizone ( $1 \% \mathrm{vol} / \mathrm{vol})$. Cells were cultured in sterile Petri dishes $\left(10-\mathrm{cm}\right.$ diameter) maintained in an incubator at $37^{\circ} \mathrm{C}$ with a humidified atmosphere containing $5 \% \mathrm{CO}_{2}$ and $95 \% \mathrm{O}_{2}$. For the incubations $\left(3-30 \mathrm{hr}, 37^{\circ} \mathrm{C}\right)$, the culture medium was replaced by Krebs-Henseleit buffer $(\mathrm{NaCl}, 119 \mathrm{mM} ; \mathrm{KCl}$, $4.7 \mathrm{mM} ; \mathrm{CaCl}_{2}, 1.3 \mathrm{mM} ; \mathrm{MgSO}_{4}, 1.2 \mathrm{mM}$; HEPES, $15 \mathrm{mM}$; and $\mathrm{KH}_{2} \mathrm{SO}_{4}, 1.2 \mathrm{mM}$ ) containing $50 \%$ (vol/vol) ${ }^{2} \mathrm{H}_{2} \mathrm{O}$ with the following combinations of ${ }^{13} \mathrm{C}$-labeled substrates: (1) $5 \mathrm{mM}\left[3-{ }^{13} \mathrm{C}\right]$ lactate; (2) $2.5 \mathrm{mM}\left[1-{ }^{13} \mathrm{C}\right]$ glucose $+3.98 \mathrm{mM}$ $\left[\mathrm{U}_{-}{ }^{13} \mathrm{C}_{3}\right]$ lactate; (3) $2.5 \mathrm{mM}\left[1-{ }^{13} \mathrm{C}\right]$ glucose $+3.93 \mathrm{mM}$ $\left[2-{ }^{13} \mathrm{C}\right]$ pyruvate; and (4) $2.5 \mathrm{mM}\left[1-{ }^{13} \mathrm{C}\right]$ glucose. Aliquots $(1 \mathrm{~mL})$ from the medium were collected during the incubation period to measure the rates of substrate utilization and product formation by ${ }^{13} \mathrm{C}$ NMR and conventional spectrophotometric methods.

\section{$\left({ }^{13} \mathrm{C},{ }^{2} \mathrm{H}\right)$ NMR Spectroscopy}

Proton-decoupled ${ }^{13} \mathrm{C}$ NMR spectra from $0.5-\mathrm{mL}$ aliquots of the incubation medium were obtained at 11.9 Tesla $\left(125.13 \mathrm{MHz}, 25^{\circ} \mathrm{C}, \mathrm{pH} 7.2\right)$ with a Bruker AVANCE 500WB NMR spectrometer using a commercial $(5-\mathrm{mm})$ triple resonance probe $\left({ }^{1} \mathrm{H},{ }^{13} \mathrm{C},{ }^{2} \mathrm{H}\right)$ optimized for direct ${ }^{13} \mathrm{C}$ NMR detection. Acquisition conditions were: $\pi / 3$ pulses; $30.0 \mathrm{kHz}$ spectral width; $1.09 \mathrm{sec}$ acquisition time; $64 \mathrm{k}$ words data table; and $6.0 \mathrm{sec}$ recycling time. Proton decoupling was gated on only during the acquisition using a broadband composite pulse decoupling (CPD) sequence that removed the scalar ${ }^{13} \mathrm{C}-{ }^{1} \mathrm{H}$ multiplets, maintaining ${ }^{13} \mathrm{C}-{ }^{13} \mathrm{C}$ and ${ }^{13} \mathrm{C}-{ }^{2} \mathrm{H}$ couplings. Chemical shifts were calibrated with an external reference of dioxane (10\% vol/vol, 67.4 parts per million [ppm]). Resonance assignments were based on literature values and on the addition of internal standards (Cerdán et al., 1990; Fan, 1996). Spectra deconvolution and multiplet structures were analyzed using NUTS (Acorn, Freemont, CA), a PC-based (Intel Centrino Platform) NMR program.

High-resolution ${ }^{13} \mathrm{C}$ NMR is well suited to detect complex deuteration patterns in ${ }^{13} \mathrm{C}$-labeled metabolites. This happens because the presence of one or more ${ }^{2} \mathrm{H}$ atoms bound vicinally or geminally to the observed ${ }^{13} \mathrm{C}$ results in the appearance of characteristic ${ }^{2} \mathrm{H}$-induced isotopic shifts and ${ }^{13} \mathrm{C}-{ }^{2} \mathrm{H}$ couplings (Hansen, 1983, 1988). In the case of $\left[3-{ }^{13} \mathrm{C}\right]$ lactate, the substitution of one of the $\mathrm{H} 3$ hydrogens of the methyl group by one deuteron causes the geminal C3 methyl resonance to be shifted $\left(\Delta_{1} \sim-0.27 \mathrm{ppm}\right)$ as well as split into a 1:1:1 triplet $\left({ }^{1} \mathrm{~J}_{2} \mathrm{H}^{-13} \mathrm{C}=19.5 \mathrm{~Hz}\right)$. A smaller isotopic shift is also detected in the C3 lactate resonance $\left(\Delta_{2}=-0.11 \mathrm{ppm}\right)$, upon deuterium substitution of the vicinal $\mathrm{H} 2$ hydrogen by a deuteron. In this case, the singlet multiplicity of the original ${ }^{13} \mathrm{C}$ resonance is maintained because the vicinal coupling constant ${ }^{2} \mathrm{H}-{ }^{13} \mathrm{C}$ is too small to be resolved. The isotopic shifts are additive and thus analysis of shifted and unshifted $\left({ }^{1} \mathrm{H},{ }^{2} \mathrm{H},{ }^{13} \mathrm{C}\right)$ multiplets of the lactate $\mathrm{C} 3$ resonance allows one to detect the number of deuterium replacements both in C3 and C2 carbons of [3- ${ }^{13}$ C]lactate (Moldes et al., 1994; Chapa et al., 2000; GarcíaMartín et al., 2001a, 2002).

\section{Other Determinations}

Glucose and lactate concentration in the incubation media were determined spectrophotometrically using classic enzymatic endpoint methods (Bergmeyer, 1983) coupled to the increase or decrease in $\mathrm{NAD}(\mathrm{P}) \mathrm{H}$ absorption at $340 \mathrm{~nm}$. Conventional 
methods were adapted to become operative using 96-well microplates $(0.25 \mathrm{~mL}$ ) and a vertical microplate reader (Molecular Devices, Spectramax, CA). Protein concentrations were measured using the bicinchoninic acid (BCA) assay (Sigma, St. Louis, MO). Linear $(\mathrm{y}=\mathrm{mx}+\mathrm{b})$ and nonlinear exponential $\left(\mathrm{y}=\mathrm{a}\left[1-\mathrm{e}^{-\mathrm{bx}}\right]\right)$ fittings were carried out using the Sigma Plot

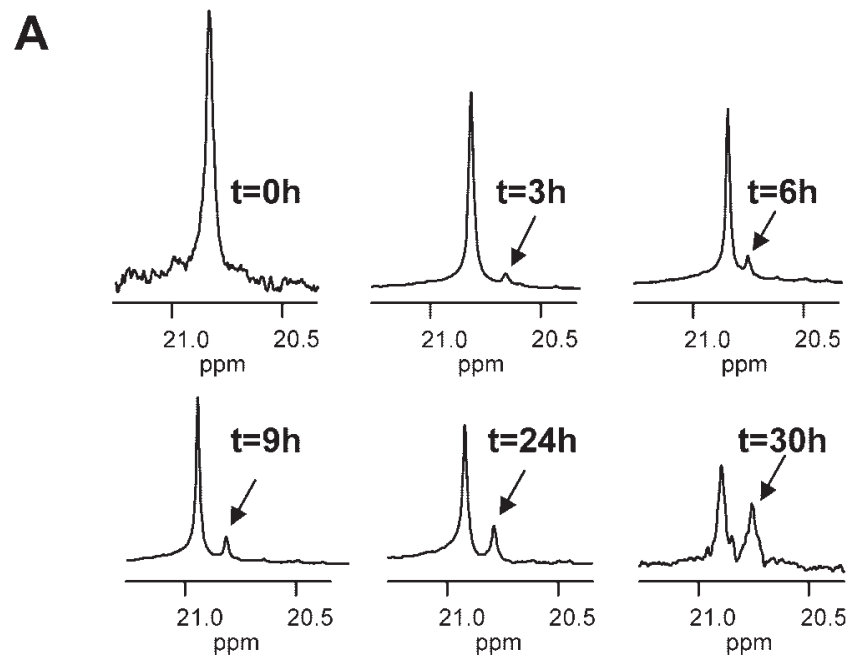

B

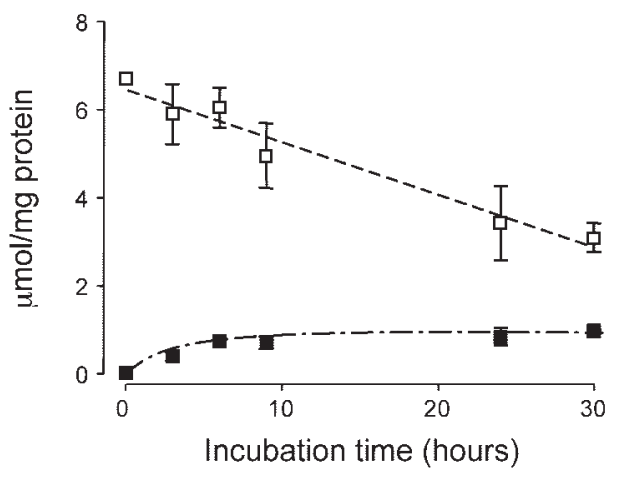

C

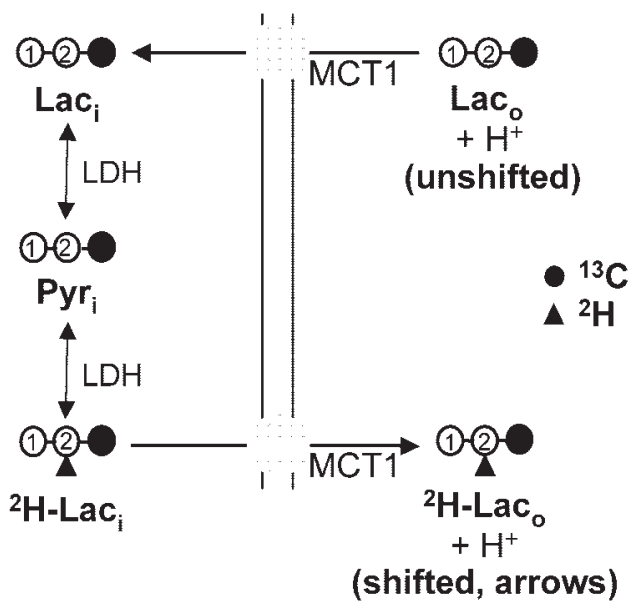

Figure 1. program (SPSS Inc., Chicago, IL) as implemented on a Intel Centrino platform.

\section{Materials}

$\left[1-{ }^{13} \mathrm{C}\right]$ Glucose, $\left[\mathrm{U}_{-}{ }^{13} \mathrm{C}_{3}\right]$ lactate, $\left[2-{ }^{13} \mathrm{C}\right]$ pyruvate, $\left[3-{ }^{13} \mathrm{C}\right]-$ lactate $\left(99.9 \%{ }^{13} \mathrm{C}\right)$ and deuterated solvents were obtained from Cambridge Isotope Laboratories (Andover, MA). ${ }^{2} \mathrm{H}_{2} \mathrm{O}(99.9 \%$ ${ }^{2} \mathrm{H}$ ) was obtained from Apollo Scientific Ltd. (Stockport, Cheshire, UK). Auxiliary enzymes and cofactors were from Boehringer Mannheim (Germany). FBS and DMEM were purchased from GIBCO BRL (Gent, Belgium). The rest of the products were of the highest purity available commercially from Sigma.

\section{RESULTS}

We propose to investigate lactate recycling using the methodology presented in Figure 1. Figure 1A illustrates the results of a representative experiment with C6 glioma cells incubated with $5 \mathrm{mM}\left[3-{ }^{13} \mathrm{C}\right]$ lactate in the presence of Krebs-Henseleit buffer containing $50 \%{ }^{2} \mathrm{H}_{2} \mathrm{O}$. ${ }^{13} \mathrm{C}$ NMR analysis of aliquots taken from the medium at increasing incubation times showed: (1) a linear decrease in the intensity of the singlet resonance from C3 lactate $(\sim 20.85 \mathrm{ppm})$; and (2) an exponential increase in the intensity of a vicinally shifted singlet from $\left[3-{ }^{13} \mathrm{C}\right.$, $\left.2-{ }^{2} \mathrm{H}\right]$ lactate $(\sim 20.74 \mathrm{ppm}$, arrows $)$. A summary of three similar experiments is shown in Figure 1B. The shifted lactate resonances (Fig. 1A, arrows) do not appear in cell-free incubations of Krebs-Henseleit buffer $(50 \%$ ${ }^{2} \mathrm{H}_{2} \mathrm{O}$ ) with $\left[3-{ }^{13} \mathrm{C}\right]$ lactate, nor during incubations of C6 cells with $\left[3-{ }^{13} \mathrm{C}\right]$ lactate in undeuterated Krebs-Henseleit buffer (not shown). These results indicate that the shifted resonances are derived from the methyl group of $\left[3-{ }^{13} \mathrm{C}\right.$, $\left.2{ }^{2} \mathrm{H}\right]$ lactate as produced by the enzymatic deuteration of intracellular $\left[3-{ }^{13} \mathrm{C}\right]$ lactate in its $\mathrm{C} 2$ carbon. This process necessarily involves the cytosolic lactate dehydrogenase (LDH) equilibrium:

$$
\begin{aligned}
\text { Pyruvate }+ \text { NAD } & \left({ }^{2} \mathrm{H}\right)+\mathrm{H}^{+} \\
\leftrightarrow & \left.\leftrightarrow 2{ }^{2} \mathrm{H}\right] \text { Lactate }+\mathrm{NAD}^{+}
\end{aligned}
$$

The sequence of events is illustrated in Figure 1C. Extracellular lactate enters the cytoplasm of the C6 cell

Fig. 1. Demonstration of lactate recycling by ${ }^{13} \mathrm{C}$ NMR $(125.13 \mathrm{MHz}$, $\left.25^{\circ} \mathrm{C}, \mathrm{pH} 7.2\right)$ in the medium of C6 glioma cells incubated with $5 \mathrm{mM}$ $\left[3-{ }^{13} \mathrm{C}\right]$ lactate in buffer containing $50 \%{ }^{2} \mathrm{H}_{2} \mathrm{O}$. A: Representative time course of the ${ }^{13} \mathrm{C}$ resonances from the methyl groups of $\left[3-{ }^{13} \mathrm{C}\right]$ and $\left[3-{ }^{13} \mathrm{C}, 2-{ }^{2} \mathrm{H}\right]$ lactate (arrows). B: Linear $\left[3-{ }^{13} \mathrm{C}\right]$ lactate consumption (empty squares) and exponential $\left[3-{ }^{13} \mathrm{C}, 2-{ }^{2} \mathrm{H}^{2}\right]$ lactate production (full squares). C: Extracellular $\left[3-{ }^{13} \mathrm{C}\right]$ lactate $\left(\mathrm{Lac}_{\mathrm{o}}\right.$, unshifted) enters the cytosol $\left(\mathrm{Lac}_{\mathrm{i}}\right)$ through the MCT1 transporter. $\left[3-{ }^{13} \mathrm{C}\right] \mathrm{Lac}_{\mathrm{i}}$ loses its $\mathrm{H} 2$ hydrogen and incorporates a deuteron from $\operatorname{NAD}\left({ }^{2} \mathrm{H}\right)$ in the lactate dehydrogenase (LDH) equilibrium. $\left[3-{ }^{13} \mathrm{C}, 2-{ }^{2} \mathrm{H}\right] \mathrm{Lac}_{\mathrm{i}}$ abandons the cell through the reversible MCT1 transporter originating the shifted singlet $\left({ }^{2} \mathrm{H}-\mathrm{Lac}_{\mathrm{o}}\right)$ in the incubation medium detected in Fig. 1A (arrows). LDH, lactate dehydrogenase; MCT1, monocarboxylate transporter 1. 
through the MCT1 transporter. Once in the cytosol, it loses its $\mathrm{H} 2$ hydrogen by exchange with one deuteron from the solvent, incorporated through the lactate dehydrogenase equilibrium (equation 1). Finally, the cytosolic $\left[3-{ }^{13} \mathrm{C}, 2-{ }^{2} \mathrm{H}\right]$ lactate produced in this way may eventually abandon the cell (together with a $\mathrm{H}^{+}$) through the reversible MCT1 transporter, becoming detectable by ${ }^{13} \mathrm{C}$ NMR in the incubation medium (Fig. 1A arrows, Fig. 1B). Intracellular $\left[3-{ }^{13} \mathrm{C}\right]$ lactate, however, may be either oxidized in the TCA cycle, resulting in the linear decrease of the total signal intensity from $\left[3-{ }^{13} \mathrm{C}\right]$ lactate, or recycled to the incubation medium, originating the exponential increase of the isotopically shifted singlets shown in Figure $1 \mathrm{~A}$ and $1 \mathrm{~B}$, respectively. In these experiments, it was possible to determine a net $\left[3-{ }^{13} \mathrm{C}\right]$ lactate consumption of $0.119 \pm 0.012 \mu \mathrm{mol} / \mathrm{mg}$ protein $/ \mathrm{hr}$ and a time constant for lactate extrusion of $0.227 \pm 0.031 / \mathrm{hr}$. For an intracellular lactate concentration of $\sim 5 \mathrm{mM}$, it is possible to calculate a lactate extrusion flux of $1.135 \pm$ $0.155 \mu \mathrm{mol} / \mathrm{mg}$ protein $/ \mathrm{hr}$ under these conditions. This indicates that lactate equilibration through the MCT is very rapid, occurring approximately 10 times faster than the net lactate uptake. At the end of these experiments, the relative ratios of shifted and unshifted areas of the methyl resonances of lactate approached 1.1, suggesting that molecules of $\left[3-{ }^{13} \mathrm{C}\right]$ lactate deuterated and nondeuterated in C2 lactate have virtually reached equilibrium with the $\sim 50 \%$ deuterated solvent.

Figure 2 shows that lactate recycling is also observed in the presence of physiologic concentrations of glucose. In this experiment, C6 cells were incubated with $2.5 \mathrm{mM}$ $\left[1-{ }^{13} \mathrm{C}\right]$ glucose and $3.98 \mathrm{mM}\left[\mathrm{U}_{-}{ }^{13} \mathrm{C}_{3}\right]$ lactate in KrebsHenseleit buffer containing $50 \%{ }^{2} \mathrm{H}_{2} \mathrm{O}$. Because the C3 resonance derived from $\left[\mathrm{U}_{-}{ }^{13} \mathrm{C}_{3}\right]$ lactate is a doublet $\left({ }^{1} \mathrm{~J}_{\mathrm{C} 2-\mathrm{C} 3}=37.0 \mathrm{~Hz}\right)$ whereas the lactate $\mathrm{C} 3$ resonance derived from $\left[1-{ }^{13} \mathrm{C}\right]$ glucose is a singlet, it became possible to follow simultaneously the changes in concentration of the different $\left({ }^{13} \mathrm{C},{ }^{2} \mathrm{H}\right)$ lactate isotopomers derived from $\left[1-{ }^{13} \mathrm{C}\right]$ glucose or $\left[\mathrm{U}_{-}{ }^{13} \mathrm{C}_{3}\right]$ lactate, respectively. Figure $2 \mathrm{~A}$ shows that $\left[3-{ }^{13} \mathrm{C}\right]$ lactate production from $\left[1-{ }^{13} \mathrm{C}\right]$ glucose was negligible as judged from the virtually unobservable $\left[3-{ }^{13} \mathrm{C}\right]$ lactate singlet after 9-hr incubation (dotted arrow). Under these conditions, most of the recycled lactate (full arrows) was the doublet derived from the methyl group of $\left[\mathrm{U}_{-}{ }^{13} \mathrm{C}_{3},{ }^{2-}{ }^{2} \mathrm{H}\right]$ lactate, as produced from added $\left[\mathrm{U}_{-}{ }^{13} \mathrm{C}_{3}\right.$ ]lactate. Consumption of glucose (expressed in triose units) and lactate were linear with values of $0.240 \pm$ 0.084 and $0.360 \pm 0.071 \mu \mathrm{mol} / \mathrm{mg}$ protein $/ \mathrm{hr}$, respectively (Fig. 2B). Lactate extrusion was exponential, with a time constant of $0.489 \pm 0.082 / \mathrm{hr}$, corresponding with $\sim 4 \mathrm{mM}$ lactate, to a recycled lactate efflux of $1.94 \pm$ $0.34 \mu \mathrm{mol} / \mathrm{mg}$ protein $/ \mathrm{hr}$. Lactate recycling therefore seems to occur, again in this case, significantly faster than does glucose or lactate metabolism.

We next investigated the effect of a more oxidized substrate on lactate production and recycling from glucose. C6 cells were incubated with $3.93 \mathrm{mM}$ $\left[2-{ }^{13} \mathrm{C}\right]$ pyruvate and $2.5 \mathrm{mM}\left[1-{ }^{13} \mathrm{C}\right]$ glucose in Krebs-
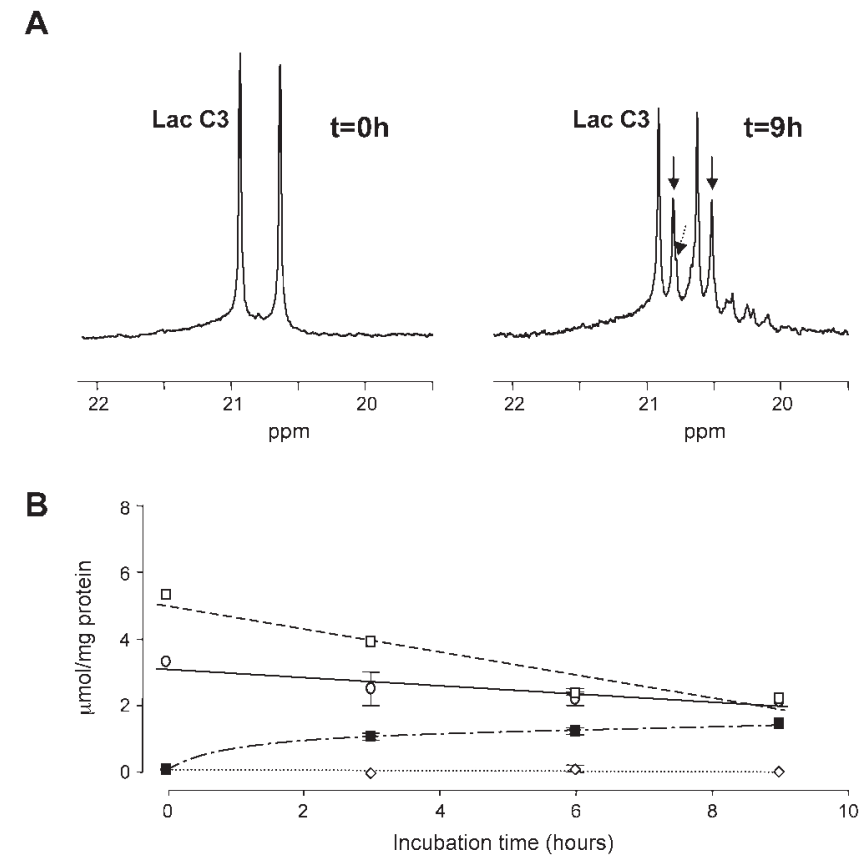

Fig. 2. Lactate recycling during metabolism of $2.5 \mathrm{mM}\left[1-^{13} \mathrm{C}\right]$ glucose and $3.98 \mathrm{mM}\left[\mathrm{U}_{-}{ }^{13} \mathrm{C}_{3}\right]$ lactate in buffer containing $50 \%{ }^{2} \mathrm{H}_{2} \mathrm{O}$ as detected by ${ }^{13} \mathrm{C}$ NMR $\left(125.13 \mathrm{MHz}, 25^{\circ} \mathrm{C}, \mathrm{pH} 7.2\right)$. A: Doublet resonances from the methyl groups of $\left[\mathrm{U}_{-}{ }^{13} \mathrm{C}_{3}\right]$ or $\left[\mathrm{U}_{-}{ }^{13} \mathrm{C}_{3}\right.$, $\left.2{ }^{2} \mathrm{H}\right]$ lactate (full arrows) at $0-\mathrm{hr}$ and $9-\mathrm{hr}$ incubation time. Note the reduced intensity of the $\left[3-{ }^{13} \mathrm{C}\right]$ lactate singlet derived from $\left[1-{ }^{13} \mathrm{C}\right]$ glucose after 9-hr incubation (dotted arrow). B: Linear consumption of $\left[\mathrm{U}_{-}{ }^{13} \mathrm{C}_{3}\right]$ lactate (empty squares) and $\left[1-{ }^{13} \mathrm{C}\right]$ glucose (empty circles). Exponential production of $\left[\mathrm{U}_{-}{ }^{13} \mathrm{C}_{3}, 2-{ }^{2} \mathrm{H}\right]$ lactate (full squares). Note the small production of $\left[3-{ }^{13} \mathrm{C}\right]$ lactate (empty diamonds).

Henseleit buffer containing $50 \%{ }^{2} \mathrm{H}_{2} \mathrm{O}$ (Fig. 3A). Under these conditions, $\left[3-{ }^{13} \mathrm{C}\right]$ lactate and $\left[3-{ }^{13} \mathrm{C}, 2-{ }^{2} \mathrm{H}\right]$ lactate (full arrow) were produced from glucose in small but approximately equal amounts. Notably, no significant amounts of $\left[2-{ }^{13} \mathrm{C}, 2-{ }^{2} \mathrm{H}\right]$ lactate derived from $\left[2-{ }^{13} \mathrm{C}\right]$ pyruvate were observed, as revealed by the absence of the corresponding 1:1:1 triplets reflecting geminal ${ }^{13} \mathrm{C}-{ }^{2} \mathrm{H}$ coupling of lactate $\mathrm{C} 2$ (dotted arrow). Moreover, the lactate $\mathrm{C} 2$ resonance depicted a 1:2:1 structure, revealing the additive isotopic shifts $(\Delta=-0.045 \mathrm{ppm})$ from a 1:2:1 mixture of vicinally deuterated isotopomers: $\left[2-{ }^{13} \mathrm{C}\right],\left[2-{ }^{13} \mathrm{C}, 3-{ }^{2} \mathrm{H}\right]$, and $\left[2-{ }^{13} \mathrm{C}, 3,3{ }^{\prime}-{ }^{2} \mathrm{H}_{2}\right]$ lactate, respectively. This distribution is consistent with an equilibrium deuteration on the two exchangeable hydrogens of the methyl carbon of $\left[2-{ }^{13} \mathrm{C}\right]$ lactate, derived from $\left[3-{ }^{13} \mathrm{C}\right.$, $\left.3-{ }^{2} \mathrm{H}\right]$ or $\left[3-{ }^{13} \mathrm{C}, 3,3^{\prime}-{ }^{2} \mathrm{H}_{2}\right]$ malate in the TCA cycle. $\left[2-{ }^{13} \mathrm{C}\right]$ Lactate produced from $\left[2-{ }^{13} \mathrm{C}\right]$ pyruvate thus does not seem to incorporate deuterons in $\mathrm{H} 2$, whereas $\left[1-{ }^{13} \mathrm{C}\right]$ glucose produces similar amounts of $\left[3-{ }^{13} \mathrm{C}\right]$ and $\left[3-{ }^{13} \mathrm{C}, 2-{ }^{2} \mathrm{H}\right]$ lactate. In these experiments, $\left[2-{ }^{13} \mathrm{C}\right]-$ pyruvate consumption was linear only during the first $4 \mathrm{hr}$ of the experiment as $1.087 \pm 0.110 \mu \mathrm{mol} / \mathrm{mg}$ protein $/ \mathrm{hr}$. Glucose consumption remained linear for a longer period, 
A
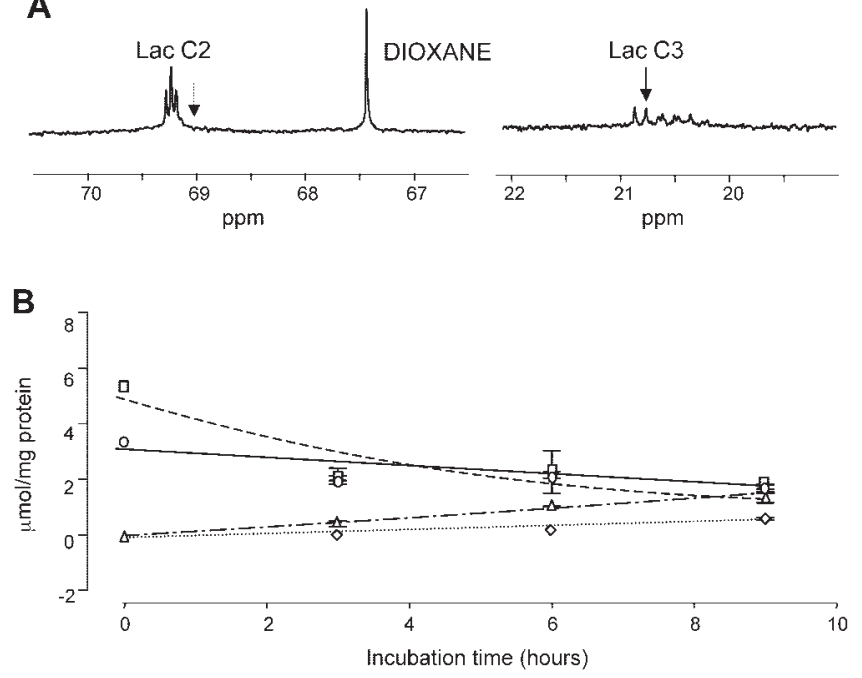

Fig. 3. Lactate recycling during metabolism of $2.5 \mathrm{mM}\left[1-{ }^{13} \mathrm{C}\right]$ glucose and $3.93 \mathrm{mM}\left[2-{ }^{13} \mathrm{C}\right]$ pyruvate in Krebs-Henseleit buffer $\left(50 \%{ }^{2} \mathrm{H}_{2} \mathrm{O}\right)$ as detected by ${ }^{13} \mathrm{C}$ NMR $\left(125.13 \mathrm{MHz}, 25^{\circ} \mathrm{C}, \mathrm{pH}\right.$ 7.2). A: Singlet resonances from $\left[2-{ }^{13} \mathrm{C}\right]$ lactate $\left(69.3 \mathrm{ppm}\right.$, left panel) and $\left[3-{ }^{13} \mathrm{C}\right]$ lactate (20.85 ppm, right panel) after 9-hr incubation. Note the 1:2:1 distribution of the $\left[2{ }^{13} \mathrm{C}\right]$ lactate resonances and the absence of the 1:1:1 triplet of $\left[2-{ }^{13} \mathrm{C}, 2-{ }^{2} \mathrm{H}\right]$ lactate (dotted arrow). Note the $1: 1$ ratio of shifted (full arrow)/unshifted singlets in $\left[3-{ }^{13} \mathrm{C}\right]$ lactate. B: Consumption of $\left[2-{ }^{13} \mathrm{C}\right]$ pyruvate (empty squares) or $\left[1-{ }^{13} \mathrm{C}\right]$ glucose (empty circles) and production of $\left[2-{ }^{13} \mathrm{C}\right]$ lactate (empty triangles) or $\left[3-{ }^{13} \mathrm{C}\right]-$ lactate (empty diamonds).

with a value of $0.350 \pm 0.110 \mu \mathrm{mol} / \mathrm{mg}$ protein $/ \mathrm{hr}$ (expressed in triose units); $\left[3-{ }^{13} \mathrm{C}\right]$ and $\left[2-{ }^{13} \mathrm{C}\right]$ lactate were produced at rates of $0.063 \pm 0.021$ and $0.155 \pm$ $0.014 \mu \mathrm{mol} / \mathrm{mg}$ protein $/ \mathrm{hr}$, respectively.

Finally, we explored the production of undeuterated and deuterated lactate molecules during the metabolism of $\left[1-{ }^{13} \mathrm{C}\right]$ glucose. C6 cells were incubated with $2.5 \mathrm{mM}$ $\left[1-{ }^{13} \mathrm{C}\right]$ glucose and the production of $\left[3-{ }^{13} \mathrm{C}\right]$ and $\left[3-{ }^{13} \mathrm{C}\right.$, $\left.2{ }^{2} \mathrm{H}\right]$ lactate (Fig. 4A, arrows) were monitored as indicated in Figure $4 \mathrm{~A}$. In this case, $\left[3-{ }^{13} \mathrm{C}\right]$ and $\left[3{ }^{13} \mathrm{C}\right.$, $\left.2-{ }^{2} \mathrm{H}\right]$ lactate were produced at a very similar rate from the very initial phases of the incubation. This suggests that as expected, the equilibration of lactate $\mathrm{C} 2$ deuteration in the lactate dehydrogenase step occurs before lactate extrusion to the medium. Because lactate is deuterated before transport to the medium, the experiments with $\left[1-{ }^{13} \mathrm{C}\right]$ glucose do not allow direct monitoring of lactate recycling through the plasma membrane, but simply the production of $\left[3-{ }^{13} \mathrm{C}\right]$ and $\left[3-{ }^{13} \mathrm{C}, \quad 2-{ }^{2} \mathrm{H}\right]$ lactate from $\left[1-{ }^{13} \mathrm{C}\right]$ glucose. $\left[1-{ }^{13} \mathrm{C}\right]$ Glucose consumption (expressed in triose units) was $0.706 \pm 0.078 \mu \mathrm{mol} / \mathrm{mg}$ protein $/ \mathrm{hr}$, whereas $\left[3-{ }^{13} \mathrm{C}\right]$ and $\left[3-{ }^{13} \mathrm{C}, 2-{ }^{2} \mathrm{H}\right]$ lactate production were $0.013 \pm 0.004$ and $0.015 \pm 0.002 \mu \mathrm{mol} / \mathrm{mg}$ protein/hr, respectively. Notably, the similar rates of production of the undeuterated and deuterated species suggest a negligible deuterium kinetic isotopic effect in this process. A summary of the metabolic balances obtained during these experiments is presented in Table I.
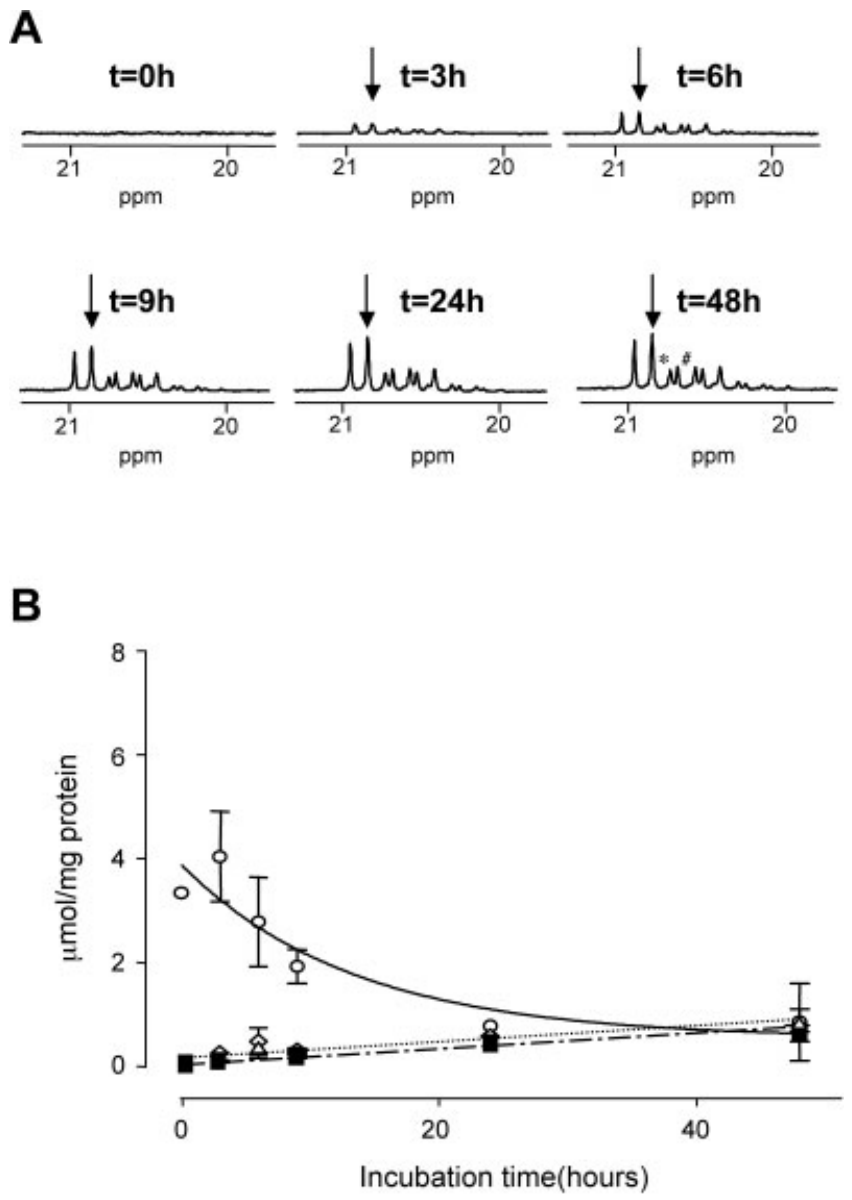

Fig. 4. Metabolism of $\left[1-{ }^{13} \mathrm{C}\right]$ glucose in Krebs-Henseleit buffer $(50 \%$ $\left.{ }^{2} \mathrm{H}_{2} \mathrm{O}\right)$ as detected by ${ }^{13} \mathrm{C}$ NMR $\left(125.13 \mathrm{MHz}, 25^{\circ} \mathrm{C}, \mathrm{pH}\right.$ 7.2). A: Time course of production of $\left[3-{ }^{13} \mathrm{C}\right]$ and $\left[3-{ }^{13} \mathrm{C}, 2-{ }^{2} \mathrm{H}\right]$ lactate (arrow). Multiplets at higher field correspond to $\left.\left[3{ }^{13} \mathrm{C}, 3{ }^{2} \mathrm{H}\right]\right]^{\star}$ and $\left[3-{ }^{13} \mathrm{C}, 3-{ }^{2} \mathrm{H}, 2-{ }^{2} \mathrm{H}\right] \#$ lactate, originating from $\left[3-{ }^{13} \mathrm{C}, 3-{ }^{2} \mathrm{H}\right]$ and $\left[3-{ }^{13} \mathrm{C}, 3,3^{\prime}-{ }^{2} \mathrm{H}_{2}\right]$ malate in the TCA cycle. B: Consumption of $\left[1-{ }^{13} \mathrm{C}\right]$ glucose (empty circles) and production of $\left[3-{ }^{13} \mathrm{C}\right]$ and $\left[3-{ }^{13} \mathrm{C}\right.$, $\left.2{ }^{2} \mathrm{H}\right]$ lactate.

\section{DISCUSSION}

Lactate exchange between the intra- and extracellular spaces is thought to be a very fast process occurring in both directions because of the reversible nature of the MCT of the plasma membrane (Poole and Halestrap, 1993; Jackson and Halestrap, 1996; Halestrap and Price, 1999; Halestrap and Meredith, 2004). These transporters are believed to operate under near thermodynamic equilibrium conditions, carrying one molecule of lactate and one proton in the inward or outward directions depending on the corresponding transmembrane gradients of lactate and protons:

$$
\text { Lactate }_{\text {in }}+\mathrm{H}_{\text {in }}{ }^{+} \leftrightarrow \text { Lactate }_{\text {out }}+\mathrm{H}_{\text {out }}{ }^{+}
$$

Lactate exchange entails important physiologic consequences. In particular, it sets the lactate concentration in 
TABLE I. Metabolic Balances of Substrate Consumption, Product Formation, and Lactate Recycling in C6 Cells Incubated With Different Combinations of ${ }^{13} \mathrm{C}-$ Labeled Substrates in $50 \%$ Deuterated Krebs-Henseleit Buffer ${ }^{\star}$

\begin{tabular}{|c|c|c|c|c|c|c|}
\hline Incubation conditions & \multicolumn{6}{|c|}{ Process investigated } \\
\hline $\begin{array}{l}2.5 \mathrm{mM}\left[1-{ }^{13} \mathrm{C}\right] \mathrm{Glc}+ \\
\quad 3.98 \mathrm{mM}\left[\mathrm{U}^{13}{ }^{13} \mathrm{C}_{3}\right] \mathrm{Lac}\end{array}$ & $0.240 \pm 0.084$ & $0.360 \pm 0.071(\mathrm{~L})$ & $0.003 \pm 0.008$ & $0.489 \pm 0.082$ & $0.237 \pm 0.092$ & $0.360 \pm 0.071(\mathrm{~L})$ \\
\hline $\begin{array}{l}2.5 \mathrm{mM}\left[1-{ }^{13} \mathrm{C}\right] \mathrm{Glc}+ \\
\quad 3.93 \mathrm{mM}\left[2-{ }^{13} \mathrm{C}\right] \mathrm{Pyr}\end{array}$ & $0.350 \pm 0.110$ & $0.152 \pm 0.060(\mathrm{P})$ & $\begin{array}{l}0.063 \pm 0.021^{\mathrm{d}} \\
0.155 \pm 0.014^{\mathrm{e}}\end{array}$ & $\mathrm{ND}^{\mathrm{b}}$ & $0.287 \pm 0.131$ & $0.152 \pm 0.060(\mathrm{P})$ \\
\hline
\end{tabular}

$\star^{\star} \mathrm{C} 6$ cells were incubated in Krebs-Henseleit buffer containing $50 \%{ }^{2} \mathrm{H}_{2} \mathrm{O}$ with the specified ${ }^{13} \mathrm{C}$-labeled substrates. Values are expressed in $\mu \mathrm{mol} / \mathrm{mg}$ protein/hr as the mean \pm standard deviation of at least three replicates. Glc, glucose; Lac, lactate; Pyr, pyruvate; NA, not applicable; ND, not detectable. ${ }^{a}$ Expressed in triose units.

${ }^{b}$ Lactate recycling from $\left[2-{ }^{13} \mathrm{C}\right]$ pyruvate or $\left[1-{ }^{13} \mathrm{C}\right]$ glucose not detectable.

${ }^{c}$ Includes the addition of $\left[3-{ }^{13} \mathrm{C}\right]$ and $\left[3-{ }^{13} \mathrm{C}, 2{ }^{2} \mathrm{H}\right]$ lactates, $0.013 \pm 0.004$ and $0.015 \pm 0.002$, respectively.

${ }^{\mathrm{d}}\left[3-{ }^{13} \mathrm{C}\right]$ Lactate produced from $\left[1-{ }^{13} \mathrm{C}\right]$ glucose.

$\left[2-{ }^{\mathrm{e}} \mathrm{C}\right]$ Lactate produced from $\left[2-{ }^{13} \mathrm{C}\right]$ pyruvate.

the intra and extracellular spaces and determines its subsequent metabolism, coupling it to the transmembrane $\mathrm{pH}$ gradient and $\mathrm{pH}$ homeostasis. Despite its importance, direct measurements of lactate exchange are complicated because of its relatively fast time scale and the need to discriminate between transport and metabolism and between lactate molecules moving inward or outward. Previous measurements used radioactive isotopes or fluorescence methods to probe extracellular lactate transport to the intracellular space (Poole and Halestrap, 1993; Jackson and Halestrap, 1996). We are unaware, however, of any previous measurements of intracellular lactate transport to the extracellular space through the proton-linked MCT of the plasma membrane.

We report on a novel procedure to investigate intracellular lactate exchange with the medium in cell cultures. The method is based on the fact that in deuterium oxide-containing media, extracellular lactate molecules entering the cytosol and exchange their $\mathrm{H} 2$ proton with a deuteron in the LDH equilibrium. In the case of $\left[3-{ }^{13} \mathrm{C}\right]$ lactate, the following cytosolic processes take place:

$$
\begin{aligned}
& {\left[3-{ }^{13} \mathrm{C}\right] \text { Lactate }+\mathrm{NAD}^{+} \leftrightarrow\left[3-{ }^{13} \mathrm{C}\right] \text { Pyruvate } } \\
&+\mathrm{NADH}+\mathrm{H}^{+}
\end{aligned}
$$

and

$$
\begin{aligned}
& {\left[3-{ }^{13} \mathrm{C}\right] \text { Pyruvate }+\mathrm{NAD}\left({ }^{2} \mathrm{H}\right)+\mathrm{H}^{+}} \\
& \leftrightarrow\left[3-{ }^{13} \mathrm{C}, 2-{ }^{2} \mathrm{H}\right] \text { Lactate }+\mathrm{NAD}^{+}
\end{aligned}
$$

The combination of both, results in the net exchange of a deuteron between $\mathrm{NADH}\left({ }^{2} \mathrm{H}\right)$ and the $\mathrm{H} 2$ hydrogen of lactate:

$$
\begin{aligned}
{\left[3-{ }^{13} \mathrm{C}\right] \text { Lactate } } & +\mathrm{NAD}\left({ }^{2} \mathrm{H}\right) \\
\leftrightarrow & {\left[3-{ }^{13} \mathrm{C}, 2-{ }^{2} \mathrm{H}\right] \text { Lactate }+\mathrm{NADH} }
\end{aligned}
$$

The $\left[3-{ }^{13} \mathrm{C}, 2-{ }^{2} \mathrm{H}\right]$ lactate originating in this way may return to the incubation medium where it is distinguished easily from $\left[3-{ }^{13} \mathrm{C}\right]$ lactate by high-resolution ${ }^{13} \mathrm{C}$ NMR, because the methyl group of the deuterated species resonates $-0.11 \mathrm{ppm}$ from the methyl group of the perprotonated species.

Deuteration of the C2 carbon of lactate requires the transfer of one deuteron from the heavy water in the solvent to $\operatorname{NAD}(\mathrm{P})^{2} \mathrm{H}$. This must involve first one hydration-dehydration reaction:

$$
\mathrm{AH}+{ }^{2} \mathrm{H}_{2} \mathrm{O} \leftrightarrow \mathrm{AH}\left({ }^{2} \mathrm{H}\right)+{ }^{2} \mathrm{HO}^{-}
$$

and second, a redox process of the general type:

$$
\mathrm{AH}\left({ }^{2} \mathrm{H}\right)+\mathrm{NAD}(\mathrm{P})^{+} \leftrightarrow \mathrm{AH}+\mathrm{NAD}(\mathrm{P})^{2} \mathrm{H}
$$

where $\mathrm{A}$ is the metabolite incorporating the ${ }^{2} \mathrm{H}$ from ${ }^{2} \mathrm{H}_{2} \mathrm{O}$ that will be transferred later to $\mathrm{NAD}(\mathrm{P})^{+}$in the redox process. The combination of reactions in equations (6) and (7) accounts for the exchange of deuterons between ${ }^{2} \mathrm{H}_{2} \mathrm{O}$ and $\mathrm{NAD}(\mathrm{P})^{+}$:

$$
{ }^{2} \mathrm{H}_{2} \mathrm{O}+\mathrm{NAD}(\mathrm{P})^{+} \leftrightarrow \mathrm{NAD}(\mathrm{P})^{2} \mathrm{H}+{ }^{2} \mathrm{HO}^{-}
$$

These considerations account for the fact that lactate deuteration is observed easily when $\left[3-{ }^{13} \mathrm{C}\right]$ lactate or $\left[1-{ }^{13} \mathrm{C}\right]$ glucose are substrates, but becomes undetectable when $\left[2-{ }^{13} \mathrm{C}\right]$ pyruvate is the precursor. Indeed, under the reduced redox conditions prevailing during lactate or glucose and lactate metabolisms, the concentration of $\operatorname{NAD}(\mathrm{P})^{2} \mathrm{H}$ is high enough and deuterations derived from it become easily observable. Under the oxidized condi- 
Fig. 5. Intracellular pyruvate compartmentation and lactate recycling during metabolism of $\left[1-{ }^{13} \mathrm{C}\right]$ glucose and [U$\left.{ }^{13} \mathrm{C}_{3}\right]$ lactate $(\mathbf{A})$ or $\left[2-{ }^{13} \mathrm{C}\right]$ pyruvate $(\mathbf{B})$. Two kinetically different cytosolic pools of pyruvate exist in C6 cells: pyruvate pool derived from glucose $(\mathrm{Pg})$ and pyruvate pool derived from extracellular lactate or pyruvate $(\mathrm{Pp})$. Coupling of a hydration/dehydration reaction and a redox process allows $\operatorname{NAD}\left({ }^{2} \mathrm{H}\right)$ to be formed from a solvent deuteron incorporated previously in metabolite A. A: Intracellular lactate $\left(\mathrm{Lac}_{\mathrm{i}}\right)$ competes with glycolysis for $\mathrm{NAD}^{+}$, inhibiting $\left[3-{ }^{13} \mathrm{C}\right]$ lactate production. Deuteration of the $\mathrm{Pp}$ pool in the $\mathrm{LDH}$ reaction occurs extensively, extruding large amounts of $\left[\mathrm{U}_{-}{ }^{13} \mathrm{C}_{3}, 2-{ }^{2} \mathrm{H}\right]$ lactate to the medium but not of $\left[3-{ }^{13} \mathrm{C}, 2-{ }^{2} \mathrm{H}\right]$ lactate (dotted arrow). B: Intracellular lactate derived from the $\mathrm{Pp}$ pool of [2-

${ }^{13} \mathrm{C}$ ]pyruvate is formed before $\mathrm{H} 2$ deuteration can occur, extruding to the medium mainly $\left[2-{ }^{13} \mathrm{C}\right]$ lactate. Glycolytic $\left[3-{ }^{13} \mathrm{C}\right]$ pyruvate is formed significantly slower, allowing $\left[3-{ }^{13} \mathrm{C}, 2-{ }^{2} \mathrm{H}\right]-$ lactate to be formed and extruded to the medium. LDH, lactate dehydrogenase; MCT1, monocarboxylate transporter type 1 . Filled circle, ${ }^{13} \mathrm{C}$; filled triangle, ${ }^{2} \mathrm{H}$.
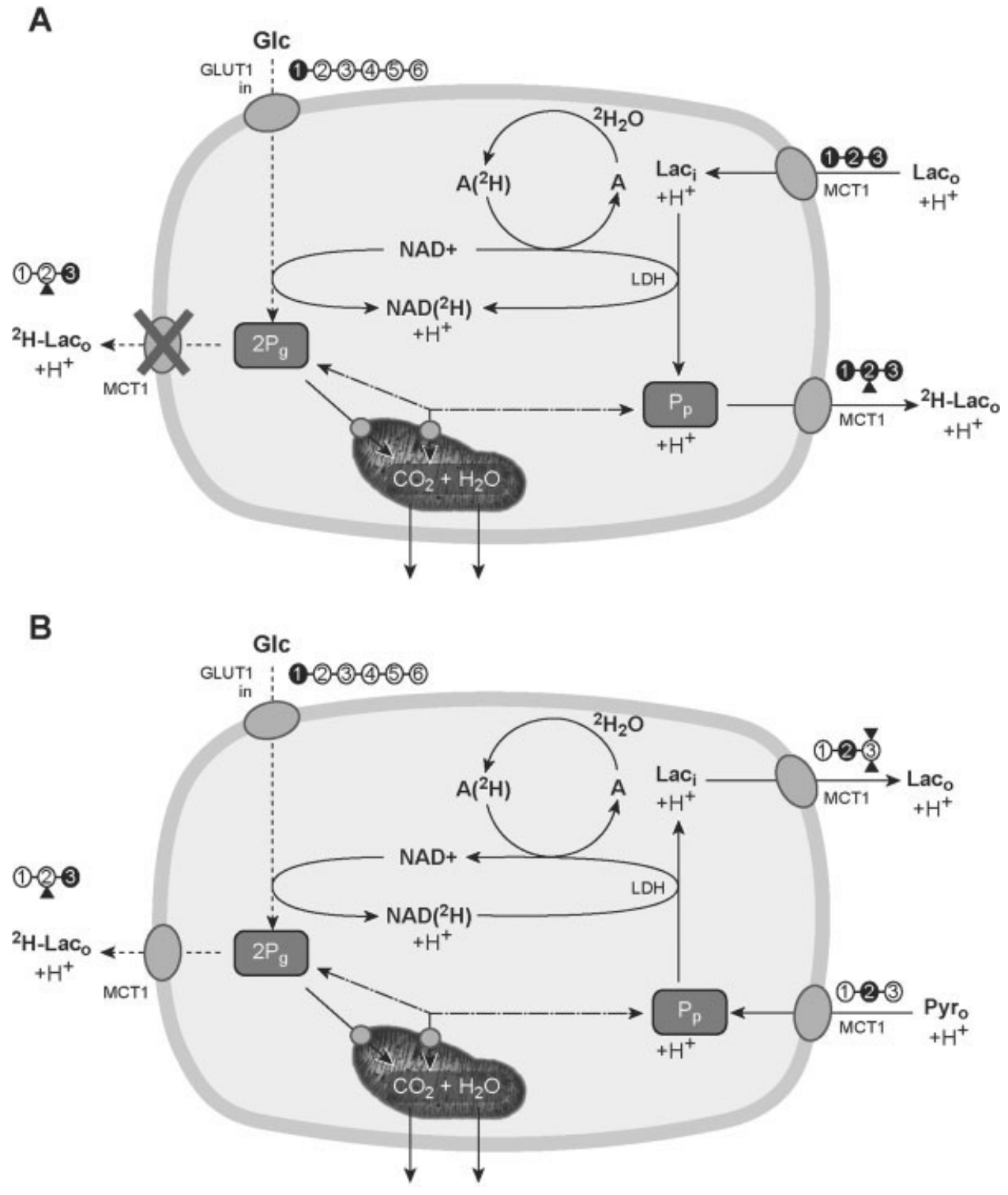

tions occurring when glucose and pyruvate are used, however, the concentration of NAD $(\mathrm{P})^{2} \mathrm{H}$ is reduced markedly, concomitantly decreasing the transfers of reducing deuterons. In addition, the much faster pyruvate $(\sim 1.07 \mu \mathrm{mol} / \mathrm{mg}$ protein $/ \mathrm{hr})$ than lactate uptake could result even faster than the combined hydrationdehydration/redox deuterations, reducing lactate deuteration from ${ }^{2} \mathrm{H}_{2} \mathrm{O}$ to negligible levels by kinetic constrains.

The present experiments provide also valuable information concerning the redox control of glycolysis. When $2.5 \mathrm{mM}\left[1-{ }^{13} \mathrm{C}\right]$ glucose is used as the only substrate, glucose consumption and lactate production rates are 0.70 (triose units) and $0.03 \mu \mathrm{mol} / \mathrm{mg}$ protein $/ \mathrm{hr}$, respectively. Incubations with $5 \mathrm{mM}\left[3-{ }^{13} \mathrm{C}\right]$ lactate alone, show that C6 cells are able to oxidize lactate at a rate of $0.12 \mu \mathrm{mol} / \mathrm{mg}$ protein $/ \mathrm{hr}$. When mixtures of $2.5 \mathrm{mM}$ $\left[1-{ }^{13} \mathrm{C}\right]$ glucose and $3.98 \mathrm{mM} \quad\left[\mathrm{U}_{-}{ }^{13} \mathrm{C}_{3}\right]$ lactate are used, however, glucose consumption is reduced to $0.240 \mu \mathrm{mol} / \mathrm{mg}$ protein $/ \mathrm{hr}$ and lactate consumption is increased to $0.36 \mu \mathrm{mol} / \mathrm{mg}$ protein $/ \mathrm{hr}$. Notably, no significant $\left[3-{ }^{13} \mathrm{C}\right]$ lactate production from $\left[1-{ }^{13} \mathrm{C}\right]$ glucose is observed under these conditions. This indicates that high extracellular lactate concentrations are able to inhibit $\left[3-{ }^{13} \mathrm{C}\right]$ lactate production from $\left[1-{ }^{13} \mathrm{C}\right]$ glucose, most probably at the glyceraldehyde-3-phosphate dehydrogenase (GAPDH) step because of the competition between lactate and glycolysis for the severely limited cytosolic pool of $\mathrm{NAD}^{+}$. Our data also show that lactate can efficiently substitute glucose for oxidation and that the presence of glucose increases lactate uptake under these conditions. Finally, when $2.5 \mathrm{mM}\left[1-{ }^{13} \mathrm{C}\right]$ glucose and $3.93 \mathrm{mM}$ $\left[2-{ }^{13} \mathrm{C}\right]$ pyruvate are used, both $\left[2-{ }^{13} \mathrm{C}\right]$ and $\left[3-{ }^{13} \mathrm{C}\right]$ lactate are produced, derived from $\left[2-{ }^{13} \mathrm{C}\right]$ pyruvate and $\left[1-{ }^{13} \mathrm{C}\right]$ glucose, respectively. This result indicates, as 
expected, that the oxidized redox state does not inhibit flux through GAPDH. Under these conditions, only $\left[3-{ }^{13} \mathrm{C}\right]$ lactate molecules are deuterated in C2. Taken together, these findings are consistent with previous reports showing pyruvate compartmentation in C6 cells and other neural cells (Bouzier et al., 1998a,b; Cruz et al., 2001; Zwingmann et al., 2001).

Figure 5 summarizes these and earlier results on pyruvate compartmentation (Cruz et al., 2001). During the incubations with $2.5 \mathrm{mM}\left[1-{ }^{13} \mathrm{C}\right]$ glucose and $3.98 \mathrm{mM}\left[\mathrm{U}_{-}{ }^{13} \mathrm{C}_{3}\right]$ lactate (Fig. 5A), both substrates compete for the same intracellular pool of $\mathrm{NAD}^{+}$. $\left[\mathrm{U}_{-}{ }^{13} \mathrm{C}_{3}\right]$ lactate transport and equilibration is significantly faster than is glycolysis, limiting glycolytic flow at the GAPDH step through $\mathrm{NAD}^{+}$depletion. Under these conditions, virtually no $\left[3-{ }^{13} \mathrm{C}\right]$ or $\left[3{ }^{13} \mathrm{C}, 2{ }^{2} \mathrm{H}\right]$ lactate are produced from glucose, because $\mathrm{NAD}\left({ }^{2} \mathrm{H}\right)$ is used much faster in reducing the cytosolic $\left[\mathrm{U}_{-}{ }^{13} \mathrm{C}_{3}\right]$ pyruvate pool originating from lactate $\mathrm{Pp}$ than in reducing the cytosolic $\left[3-{ }^{13} \mathrm{C}\right]$ pyruvate pool originating from $\left[1-{ }^{9} \mathrm{C}\right]-$ glucose Pg. Kinetic compartmentation is also observed in the incubations with $2.5 \mathrm{mM} \quad\left[1-{ }^{13} \mathrm{C}\right]$ glucose and $3.93 \mathrm{mM}\left[2-{ }^{13} \mathrm{C}\right]$ pyruvate (Fig. $5 \mathrm{~B}$ ). In this case, the fast pyruvate transport and oxidized redox do not allow the production of $\left[2-{ }^{13} \mathrm{C}, 2-{ }^{2} \mathrm{H}\right]$ lactate from the $\mathrm{Pp}$ pool; however, the slower glycolytic flow is compatible with production of $\left[3-{ }^{13} \mathrm{C}\right]$ and $\left[3-{ }^{13} \mathrm{C}, 2-{ }^{2} \mathrm{H}\right]$ lactate from the Pg pool.

In summary, using $\left({ }^{13} \mathrm{C},{ }^{2} \mathrm{H}\right) \mathrm{NMR}$, we have been able to resolve in time the deuteration of $\mathrm{C} 2$ carbon of intracellular lactate by solvent deuterons and its transport to the extracellular medium. C2 deuteration of lactate is extensive when $\left[3-{ }^{13} \mathrm{C}\right]$ lactate or combinations of $\left[3-{ }^{13} \mathrm{C}\right]-$ lactate and $\left[1-{ }^{13} \mathrm{C}\right]$ glucose are the substrates. It becomes negligible, however, when $\left[2-{ }^{13} \mathrm{C}\right]$ pyruvate is used as substrate. We also show that increased $\left[\mathrm{U}_{-}{ }^{13} \mathrm{C}_{3}\right]$ lactate concentrations in the incubation medium, such as those commonly found during neuronal excitation or during mild hypoxic or ischemic conditions, inhibit $\left[3-{ }^{13} \mathrm{C}\right]$ lactate production from $\left[1-{ }^{13} \mathrm{C}\right] g l u c o s e$, suggesting that under these conditions, lactate could become a substrate preferable to glucose.

Finally, the present methodology to evaluate lactate exchange through the plasma membrane can be extended easily to other neural cells in culture (Fonseca et al., 2004) or to other metabolites as long as they present exchangeable hydrogens becoming deuterated during the pass of the metabolite through the intracellular space.

\section{ACKNOWLEDGEMENTS}

This work was supported by the Spanish Ministry of Education and Science (SAF 2001-2245 to S.C.), Institute of Health Carlos III (FISss C03/08, G03/155 and C03/10 to S.C.), and the Community of Madrid (Strategic Group Grant 2000-3 to P.B.). T.B. Rodrigues was supported by fellowship from Fundação para a Ciência e Tecnologia/ Ministério da Ciência e Ensino Superior-Portugal (SFRH/BD/5407/2001). M. Benito and A. Sierra were predoctoral fellows of CSIC and UNED, respectively.
H.L. Gray had a fellowship from the Howard Hughes Bravo Program of the University of Arizona. Justesa Imagen SA provided a core grant supporting the NMR Facility. We thank Mr. J. Perez for careful work with the illustrations.

\section{REFERENCES}

Bergmeyer HU. 1983. Methods of enzymatic analysis: Weinheim: Verlag Chemie.

Bouzier AK, Goodwin R, de Gannes FMP, Valeins H, Voisin P, Canioni P, Merle M. 1998a. Compartmentation of lactate and glucose metabolism in C6 glioma cells. A ${ }^{13} \mathrm{C}$ and ${ }^{1} \mathrm{H}$ NMR study. J Biol Chem 273:2716227169.

Bouzier AK, Voisin P, Goodwin R, Canioni P, Merle M. 1998b. Glucose and lactate metabolism in C6 glioma cells: evidence for the preferential utilization of lactate for cell oxidative metabolism. Dev Neurosci 20:331338.

Bouzier-Sore AK, Canioni P, Merle M. 2001. Effect of exogenous lactate on rat glioma metabolism. J Neurosci Res 65:543-548.

Bouzier-Sore AK, Voisin P, Canioni P, Magistretti TJ, Pellerin T. 2003. Lactate is a preferential oxidative energy substrate over glucose for neurons in culture. J Cereb Blood Flow Metab 23:1298-1306.

Cater HL, Chandratheva A, Benham CD, Morrison B, Sundstrom LE. 2003. Lactate and glucose as energy substrates during, and after, oxygen deprivation in rat hippocampal acute and cultured slices. J Neurochem 87:1381-1390.

Cerdán S, Kunnecke B, Seelig J. 1990. Cerebral metabolism of $[1,2-$ ${ }^{13} \mathrm{C}_{2}$ ] acetate as detected by in vivo and in vitro ${ }^{13} \mathrm{C}$ NMR. J Biol Chem 265:12916-12926.

Chapa F, Cruz F, García-Martín ML, Garcia-Espinosa MA, Cerdán S. 2000. Metabolism of $\left(1-{ }^{13} \mathrm{C}\right)$ glucose and $\left(2-{ }^{13} \mathrm{C}, 2-{ }^{2} \mathrm{H}_{3}\right)$ acetate in the neuronal and glial compartments of the adult rat brain as detected by $\left[{ }^{13} \mathrm{C}\right.$, $\left.{ }^{2} \mathrm{H}\right]$ NMR spectroscopy. Neurochem Int 37:217-228.

Cruz F, Villalba M, Garcia-Espinosa MA, Ballesteros P, Bogonez E, Satrustegui J, Cerdán S. 2001. Intracellular compartmentation of pyruvate in primary cultures of cortical neurons as detected by ${ }^{13} \mathrm{C}$ NMR spectroscopy with multiple ${ }^{13} \mathrm{C}$ labels. J Neurosci Res 66:771-781.

Dienel GA, Cruz NF. 2003. Neighborly interactions of metabolicallyactivated astrocytes in vivo. Neurochem Int 43:339-354.

Dienel GA, Hertz L. 2001. Glucose and lactate metabolism during brain activation. J Neurosci Res 66:824-838.

Fan TWM. 1996. Metabolite profiling by one- and two-dimensional NMR analysis of complex mixtures. Prog NMR Spectrosc 28:161-219.

Fonseca LL, Sierra A, Santos H, Cerdán S. 2004. Lactate recycling in primary cultures of astrocytes and neurons studied by $\left({ }^{2} \mathrm{H}\right){ }^{13} \mathrm{C}-\mathrm{NMR}$ spectroscopy. Sixth International Meeting for Brain Energy Metabolism. Heraklion, Crete, Greece. p 48.

Garcia-Espinosa MA, García-Martín ML, Cerdán S. 2003. Role of glial metabolism in diabetic encephalopathy as detected by high resolution ${ }^{13} \mathrm{C}$ NMR. NMR Biomed 16:440-449.

Garcia-Espinosa MA, Rodrigues TB, Sierra A, Benito M, Fonseca C, Gray HL, Bartnik BL, García-Martín ML, Ballesteros P, Cerdán S. 2004. Cerebral glucose metabolism and the glutamine cycle as detected by in vivo and in vitro ${ }^{13} \mathrm{C}$ NMR spectroscopy. Neurochem Int 45:297-303. García-Martín ML, Ballesteros P, Cerdán S. 2001a. The metabolism of water in cells and tissues as detected by NMR methods. Prog NMR Spectrosc 39:41-77.

García-Martín ML, Garcia-Espinosa MA, Ballesteros P, Bruix M, Cerdán S. 2002. Hydrogen turnover and subcellular compartmentation of hepatic $\left[2-{ }^{13} \mathrm{C}\right]$ glutamate and $\left[3-{ }^{13} \mathrm{C}\right]$ aspartate as detected by ${ }^{13} \mathrm{C}$ NMR. J Biol Chem 277:7799-7807. 
García-Martín ML, Herigault G, Remy C, Farion R, Ballesteros P, Coles JA, Cerdán S, Ziegler A. 2001b. Mapping extracellular pH in rat brain gliomas in vivo by ${ }^{1} \mathrm{H}$ magnetic resonance spectroscopic imaging: comparison with maps of metabolites. Cancer Res 61:6524-6531.

Halestrap AP, Meredith D. 2004. The SLC16 gene family-from monocarboxylate transporters (MCTs) to aromatic amino acid transporters and beyond. Pflugers Arch 447:619-628.

Halestrap AP, Price NT. 1999. The proton-linked monocarboxylate transporter (MCT) family: structure, function and regulation. Biochem J 343:281-299.

Hansen PE. 1983. Isotope effects on nuclear shielding. Ann Rep NMR Spectrosc 15:105-234.

Hansen PE. 1988. Deuterium isotope effects on nuclear shielding. Progr NMR Spectrosc 20:207-257.

Jackson VN, Halestrap AP. 1996. The kinetics, substrate, and inhibitor specificity of the monocarboxylate (lactate) transporter of rat liver cells determined using the fluorescent intracellular $\mathrm{pH}$ indicator, $2^{\prime}, 7^{\prime}$ bis(carboxyethyl)-5(6)-carboxyfluorescein. J Biol Chem 271:861-868.

Magistretti PJ, Pellerin L. 1997. The cellular bases of functional brain imaging: evidence for astrocyte-neuron metabolic coupling. Neuroscientist 3:361-365.

Magistretti PJ, Pellerin L. 1999. Astrocytes couple synaptic activity to glucose utilization in the brain. News Physiol Sci 14:177-182.

Moldes M, Cerdán S, Erhard P, Seelig J. 1994. ${ }^{1} \mathrm{H}_{-}{ }^{2} \mathrm{H}$ exchange in the perfused rat liver metabolizing $\left[3-{ }^{13} \mathrm{C}\right]$ alanine and ${ }^{2} \mathrm{H}_{2} \mathrm{O}$ as detected by multinuclear NMR spectroscopy. NMR Biomed 7:249-262.

Muller TB, Sonnewald U, Westergaard N, Schousboe A, Petersen SB, Unsgard G. $1994 .{ }^{13} \mathrm{C}$ NMR spectroscopy study of cortical nerve cell cultures exposed to hypoxia. J Neurosci Res 38:319-326.
Pellerin L. 2003. Lactate as a pivotal element in neuron-glia metabolic cooperation. Neurochem Int 43:331-338.

Pellerin L, Bonvento G, Chatton JY, Pierre K, Magistretti PJ. 2002. Role of neuron-glia interaction in the regulation of brain glucose utilization. Diabetes Nutr Metab 15:268-273.

Pellerin L, Magistretti PJ. 2004. Neuroenergetics: calling upon astrocytes to satisfy hungry neurons. Neuroscientist 10:53-62.

Perrin A, Roudier E, Duborjal H, Bachelet C, Riva-Lavieille C, Leverve X, Massarelli R. 2002. Pyruvate reverses metabolic effects produced by hypoxia in glioma and hepatoma cell cultures. Biochimie 84:1003-1011.

Poole RC, Halestrap AP. 1993. Transport of lactate and other monocarboxylates across mammalian plasma membranes. Am J Physiol 264:761-782.

Qu H, Haberg A, Haraldseth O, Unsgard G, Sonnewald U. 2000. $\left({ }^{13}\right) \mathrm{C}$ MR spectroscopy study of lactate as substrate for rat brain. Dev Neurosci 22:429-436.

Schurr A. 2002. Energy metabolism, stress hormones and neural recovery from cerebral ischemia/hypoxia. Neurochem Int 41:1-8.

Schurr A, Payne RS, Miller JJ, Tseng MT. 2001. Preischemic hyperglycemia-aggravated damage: evidence that lactate utilization is beneficial and glucose-induced corticosterone release is detrimental. J Neurosci Res 66:782-789.

Smith D, Pernet A, Hallett WA, Bingham E, Marsden PK, Amiel SA. 2003. Lactate: a preferred fuel for human brain metabolism in vivo. J Cereb Blood Flow Metab 23:658-664.

Zwingmann C, Richter-Landsberg C, Leibfritz D. 2001. ${ }^{13} \mathrm{C}$ isotopomer analysis of glucose and alanine metabolism reveals cytosolic pyruvate compartmentation as part of energy metabolism in astrocytes. Glia 34: $200-212$. 